\title{
FRAMING THE RISK OF ISLAMIC BASED EQUITY FINANCING: AN INSIDE LOOK
}

\author{
Wiwiek Rabiatul Adawiyah \\ Universitas Jenderal Soedirman \\ (wiwiekra@gmail.com)
}

\begin{abstract}
This article is a review of the literature that aims at bringing into surface the issue of risk management in equity-based financing which is currently less attractive to Islamic banks. There are several forms of Islamic financing offered to potential borrower. Equity financing is less favorable as compared to debt financing due to high risks associated with it. Substantial numbers of strategies have been developed by researchers to mitigate the financing risks nonetheless the attempt is far from succeed. It is evidenced in the literature that both investors and financial intermediaries tend to overlooked profit and loss sharing mode of financing. Meanwhile Equity financing is adored to be the best form of financing to be offered to small business since it is operating under the principle of justice. Profit and loss sharing mechanism relieve both fund providers and borrowers from financial burden. This article shall review potential risks embedded in equity financing and strategies to overcome the problem.
\end{abstract}

Artikel ini merupakan kajian literatur yang bertujuan untuk membahas manajemen resiko bagi pembiayaan syariah berbasis ekuitas yang saat ini kurang diminati oleh bank syariah. Bank syariah menawarkan beberapa bentuk pembiayaan kepada calon nasabah. Pembiayaan berbasis bagi hasil dianggap kurang menguntungkan dibandingkan dengan pembiayaan berbasis hutang karena adanya risiko tinggi terkait pembiayaan bagi hasil. Sejumlah strategi telah dikembangkan oleh peneliti untuk meminimalisir resiko pembiayaan namun strategi tersebut masih jauh dari sukses karena belum mampu meningkatkan jumlah pembiayaan berbasis bagi hasil yang disalurkan oleh bank syariah. Meskipun demikian pembiayaan syariah berbasis ekuitas dianggap sebagai bentuk terbaik dari pembiayaan yang akan ditawarkan kepada usaha kecil karena beroperasi atas prinsip keadilan. Mekanisme pembiayaan berbasis laba rugi meringankan pihak yang bermitra, dalam hal ini bank Islam dan usaha kecil, dari beban keuangan. Artikel ini akan meninjau potensi risiko yang melekat pada pembiayaan ekuitas dan strategi untuk mengatasinya

Keywords: Equity Financing, Risk Management, Islamic Banks. 


\section{A. Introduction}

Islamic bank is a bank which operates based on Islamic principles with operational procedures built upon the provisions of the Quran and Hadith. ${ }^{1}$. The purpose of establishing Islamic banking and financial is to provide religiously acceptable services to the Muslim community. ${ }^{2}$ The operational technical settings of products and transactions of Islamic banks in Indonesia are governed by the DSN (Dewan Syariah Nasional) MUI (Majelis Ulama Indonesia).

The emergence of Islamic banking helps maintaining an efficient financial system as one of the determinant for a growing economy. Resilient and agile financial structures help the government to control and manage several macro-economic parameters. Banking is a main element of the financial system therefore it has extensive impact on the overall financial health and stability of an economy. ${ }^{3}$ Instability in the economy of a country may result from any disturbance in its banking system. In addition banking and financial system in a country create a national network of financial claims by connecting every business unit, and helps in the creation of national financial market.

Islamic banks financing modes are differ from that of the conventional banks. The earlier provide a distinct form of financial products which allow them perform as investors, instead of only as creditors. These products are operated on principles of Profit and Loss sharing policies. Every financial contracts offered by Islamic banks must be fully comply with Shariah (Islamic) laws. This paper attempts to spur further thoughts in the area of Islamic banking with the purpose of bringing into surface an alternative model of risk management in equity financing.

\section{B. Risk Management in Islamic Finance vs Conventional Finance}

Every business organization encounters risks, therefore its' survival and growth is determined by the company's ability to manage risk. Risk management is one of the determinant factors in delivering better results to its shareholders. Islamic banks acts as an agent with the depositor who is entitled to share the gains/ loss of the investment. Some people perceive Islamic banking safer than conventional banks for some reasons: each transaction must be backed up by an asset; prohibition of payment or receipt of interest; assets to

${ }^{1}$ Muhamad, Teknik Perhitungan Bagi Hasil dan Profit Margin pada Bank Syariah. (Yogyakarta: UII Press, 2004), p.1

${ }^{2}$ Hassan, M.K and Lewis, M.K., Islamic Banking and Finance at the Crossroad, 2007, can be accessed online via file://D:/kuliah/ISLAMIC\%20FINANCE/hassan-lewis-praesentation.pdf, p.2

${ }^{3}$ Akkizidis, I. and Khandelwal, S. 2008, Financial Risk Management for Islamic Banking and Finance, Hampshire: Palgrave Macmillan, 2008), p.6. 
back the transaction should not belong to prohibited activities; and there is prohibition of speculative trading. In fact, the absence of interest rates in Islamic banks does not necessarilly put the banks in a safe position. Some of the products offered - such as lease, deferred sale, and margin sale- involve uncertainty. Islamic financing relies more on equity financing rather than debt financing and hence inherently is riskier. ${ }^{4}$

Islamic banking can be riskier than conventional banking due to several reasons ${ }^{5}$ : firstly, the risk associated with the different ways of financing a project using Profit and Loss contracts. This contract places trust as the fundamental factor in conducting the business and determining the amount of profit sharing for both banks and the business partners. Thus the risks are increasing as the banks have no controlling power over the business partners in running projects. Moreover, lack of financial instruments and market which are Shariah-compliant, endanger Islamic banks into unfavorable events. The last issue related liquidity of banks which occur as a result of the unavailability of short-term money markets for Islamic finance. Some factors lead to liquidity problems are: restrictions on the sale of debt, under developed market for shortterm Islamic instruments, the lender last-resort facilities are not available ${ }^{6}$. Another dimension of high risk due to the nature of the PLS contract, because they are based on the profitability of the project rather than the creditworthiness of the borrower.

Islamic finances impose a risk sharing between fund owner and entrepreneurs implying a mutual justice between both parties. Meanwhile in conventional financing only borrowers bear the risks. Conventional financial institutions are exposed to several types of risk: credit, market, liquidity, operation, and reputation. Islamic financial institutions also exposed to the same risks on the top of that Islamic financial institution are facing equity investment risk and sharia-non compliance risks.

Therefore Islamic banks must allocate substantial amount of efforts in terms of resources and time to risk management to survive the businesses.

${ }^{4}$ Ibid., p. 298

${ }^{5}$ Sundararajan, V. and L. Errico, L., 'Islamic Financial Institutions and Products in the Global Financial System: Key Issues in Risk Management and Challenges Ahead', IMF Working Paper No. WP/02/192, International Monetary Fund, 2002., p. 5

${ }^{6}$ Chapra, M. U. and Khan, T., 'Regulation and Supervision of Islamic Banks', Occasional Paper No. 3, Islamic Research \& Training Institute, Saudi Arabia 2000. p.56. 
Slight differences on the type of risks face by Islamic banks as compared to the conventional banks make it impossible to completely adopt risk management strategy of conventional banks into the framework of Islamic banks.

The differences occur mainly as a result of the risk-sharing principles of Islamic contracts which act as the basis for developing Islamic financial products. Moreover, Islamic financial industry is emerging industry which requires further attention from all parties.

\section{Risk Sharing with stakeholders}

Stakeholders of Islamic banks demand for tight control on equity financing because of the potential of risks occurring is relatively high. Some possible reasons for such control are: first, Islamic banking investment products are based mutual sharing of risks and benefits Islamic banks and their customers. Customers are fully aware that in case of bankruptcy they are not just losing profit but also losing their initial investment, thus requiring Islamic banks to take precautions with their money. Second, in choosing for a place of investment Islamic banks must be sharia-compliance. Islamic banks must not invest their money in a company using interest; involve speculation, and gambling as well as selling unlawful product or services. Depositors and investors look for a company precisely because of this fact, at the same time realizing that doing so is a difficult task. Sharia compliance amplifies certain financial risks.

\section{Competing with a more established conventional system}

In their young age, Islamic banks are forced to compete with more established conventional banks in the industry. Thus there is a need for the younger to look at the strategy imposed by the senior in managing their business. Nonetheless, Islamic banks cannot merely copy the risk management techniques employed by the conventional banks because every business activities mus comply with Islamic law. Some adjustments are required on risk mitigation strategy to suit the requirement of sharia-compliance. Limited number of options available on Islamic financial instruments makes it even more difficult for Islamic banks to mitigate liquidity risks. Conventional banks can use capital markets and financial instruments- such as short or long term debts instruments and derivates- to reduce their liquidity risks. These options certainly cannot be used by Islamic banks because they are sharia-compliance. For instance, conventional capital markets help financial firms reduce their liquidity risk by offering certain financial instruments, such as short- or longterm debt instruments and derivatives. But these instruments are generally offlimits for Islamic firms because they aren't sharia-compliant. 
Moreover, majority of Muslim scholars prohibited the use of the same hedging techniques that conventional firms use in mitigating risks. Although few hedging techniques are recognized among Islamic firms nowadays, most Muslim scholars claimed that the techniques are sharia-compliant or not. Thus Islamic banks must be continuously innovative in their product and introducing a better risk management technique to survive stiff competition.

\section{E. Form of Equity Financing offered by Islamic Banks}

According to Sudarsono, ${ }^{7}$ generally, profit sharing principle in Islamic bank can be done in four main contracts, those are:

Al-Musharakah (partnership, project financing participation)AlMusharakah is a partnership agreement between two or more parties for a specific business, each party contributes funds (or charitable / expertise) with the agreement that the benefits and risks will be shared in accordance with the agreements.

Musharakah transaction is based on the wishes of the parties to work together to increase the value of their assets jointly. The resources of this business is consists of both tangible and intangible resources.

Specifically, the form of contribution from the party which cooperating may constitute of funds, trading asset, entrepreneurship, skill, property, equipment, intangible asset, credit-worthiness, and any other commodity that can be valued by money. 8

There are two types of Al-Musharakah; Musharakah of ownership and Musharakah akad (contract). Musharakah of ownership is created by inheritance, wills, or any other conditions that resulted in the ownership of the asset by two or more people. Musharakah akad is created by an agreement of two or more people who agree that each of them gave Musharakah funds. Musharakah akad is divided into:

a. Syirkah al-'inan

Syirkah al-'inan is a contract between two or more people. Each party gives a portion of the overall funding and participated in the work. The portion of each party, both in funds, labor or for the results not always have to be the same.

${ }^{7}$ Sudarsono, H. 2008, Bank dan Lembaga Keuangan Syariah, Deskripsi dan Ilustrasi. Yogyakarta: Ekonisia, 2008), p. 63

${ }^{8}$ Karim, A.A. 2003, Bank Islam: AnalisisFiqih dan Keuangan, The International Institute of Islamic Thought (IIIT), Jakarta. 2003. 
b. Syirkah mufawadhah

Syirkah mufawadhah is a contract between two or more people. Each party gives a portion of the overall funding and participated in the work. Gains and losses are shared equally. Funding, work, responsibility, and the debt burden are also shared equally between all parties.

c. Syirkah a'maal

Syirkah a'maal is a contact between two people in a profession to work together and share the benefits of that work. For example is two architects working in construction projects.

d. Syirkah wujuh

Syirkah Wujuh is a contract between two or more people who have a good reputation and prestige as well as experts in the business. The goods purchasing are on credit, and selling of the goods are in cash. Gains and losses are distributed according to the supplier guarantees provided by each partner.

e. Syirkah Al-mudharabah

The implementation of Al-Musharakah in this context is usually for financing a business project or venture capital

The benefits of Al-Musharakah are as follow:

1. The bank will get a certain amount of increase in the business profits while its increasing;

2. The bank payment to its customers is depend on the revenue/ bank operating results;

3. The adjusted return of principal financing is depend on the its cash flow/ cash flow from customers;

4. The bank will be more selective and cautious (prudent) to find a business that actually halal, safe and profitable.

ii. Al-mudharabah (trust financing, trust investment)

Technically al-mudharabah is a business cooperation contract between two parties in which the first party (shahibul maal) provides 100 percent of capital, while the other party being the Manager. Profits are divided according to the agreement in the contract, while the losses are borne by the owners of capital, for a loss that is not due to the negligence of the Manager.

Generally, Al-mudharabah is divided into 2, those are:

a. Mudharabah Muthlaqah

Mudharabah muthlaqah is a form of cooperation between the shahibul maal and mudharib where the business coverage is extensive and is not limited by the specifications of the type of effort, time, and area of the business.

b. Mudharabah Muqayyadah 
Mudharabah muqayyadah (restricted mudharabah/specific mudharabah), is the form of cooperation between shahibul maal and mudharib bounded by the line of the business, time, or place of the business.

Mudharabah financing in the banking industry usually applied to working capital financing such as working capital funding trade and services; specific investment (mudharabah muqayyadah) which has special fund source with some conditions set by shahibul maal.

The advantages of Mudharabah are:

a. banks will obtain increased revenue while the business profits are increasing

b. payment of funds to the customers adjusted by the income / bank operating results

c. the financing return is basically adjusted by the cash flow / cash flow of clients' business

d. Banks will be more selective and cautious (prudent) to find a business that actually halal, safe, and profitable.

The Risk of Mudharabah financing are as follow:

a. side streaming, customers use the funds not as what is contained in the contract

b. negligent and willful misconduct

c. concealment of profits by the client if the client is not honest

iii. Al-muzara'ah (harvest-yield profit sharing)

Al-muzara'ah is the cooperation in agricultural business conducted between the land owners with tenants. Landowners provide agricultural land to the tenants for cultivation and maintained in return for a certain part (percentage) of the harvest. Al-muzara'ah is often being identified with mukhabarah. However, there is a difference between them, if in muzara'ah the seeds are provided by the land owner, in mukhabarah the seeds are provided by tenants.

iv. Al-musaqah (plantation management fee based on certain portion of yield)

Al-musaqah is a simplified form of muzara'ah. Here, the tenants are only responsible the maintenance. As return, the tenants are entitled to a certain ratio of the harvest.

So, generally there are 4 types of profit sharing principle contracts in Islamic banking which are: Musharakah, Mudharabah, Muzara'ah and Musaqah. However, the practically principles applied which are frequently use in Islamic bank is Musharakah and Mudharabah.

a. Financing with supplementary contract

The supplementary contract in financing is intended not for gaining profit, but to facilitate the implementation of the financing. Supplementary 
contract consists of hiwalah (debts), rahn (pawn), qard (money lending), wakalah (representative), kafalah (bank guarantee).

b) Services products

Services products consist of Sharf (sale and purchase of foreign exchange), and ijarah (lease). Usually, the form of Ijarah is safe deposit box and custodian.

The foundation of profit sharing are stated in the holy book Al Quran as follows:

1) Teamwork doctrine in Islam aims at creating daily productive works of the society (QS. 2:190);

2) Increase well-being and prevent social misery (QS. 3:103; 5:3; 9:71,105);

3) Prevent economic oppression and unequal distribution of wealth (QS. $177: 16 ; 69: 25-37 ; 89: 17-20 ; 107: 1-7)$;

4) To protect the needy (QS. 4:5-10, 74-76; 89:17-26);

5) establish Shariah principled organization, resulting in the strong help the weak (QS. 43:32);

6) Division of labor or specialization based on mutual dependence, as well as the exchange of goods and services because it is not possible to stand alone (QS. 92:8-10; 96:6).

\section{F. Risk Sharing and Equity Finance}

One way to ascertain the vigour of the financial system is to eradicate the asset-liability risk that threatens the solvency of all financial institutions, including commercial banks. This requires commercial banks to restrict their mandates to two activities ${ }^{9}$ : (i) cash safekeeping, and (ii) investing client money in a mutual fund. Banks could accept deposits for safekeeping only (i.e., adopt a hundred percent reserve requirement), and charge a fee for providing this service and for check-writing privileges. In their intermediation capacity, banks would identify and analyze investment opportunities and would offer them to clients; the bank would charge a fee for these services as well, much like a traditional investment bank does today. A commercial bank or a non-bank financial institution would not assume any asset-liability risk on its balance sheet. Instead, gains or losses would accrue directly to client investors. An institution, however, could also invest its own equity capital in the client's investment projects as well as other projects independent of the client. In this case, the financial institution would not be assuming any asset-liability exposure, just a potential loss of a fraction of its capital, which would not endanger its solvency. Moreover, in the absence of debt and leverage, financial

${ }^{9}$ Askari, .Islamic Finance, Risk-Sharing, and International Financial Stability. Yale Journal of International affairs. March Edition.2012.p.3 
failure is localized and prevented from infecting the entire financial system. ${ }^{10}$ In the case that investments do go sour, the institution would lose some of its capital and its mutual fund investors would lose their investments. But because the bank did not borrow, it could not lose multiples of its capital, and thus endanger the solvency of other institutions. These safeguards are the basic tenets of Islamic banking and finance.

\section{G. The types Risks Face by Islamic Banks}

The philosophy of risk management in Islam is stated in the Holy Quran Surah Yusuf Verse 67 as follows:

And he said: "O my sons! Do not enter by one gate, but enter by different gates, and I cannot avail you against Allah at all. Verily! The decision rests only with Allah. In him, I put my trust and let all those that trust, put their trust in Him

Hadist from the Prophet Muhammad s.a.w:

The Prophet Muhammad (peace be upon him) once asked a Bedouin who had left his camel untied, "Why do you not tie your camel?" The Bedouin answered, "I put my trust in God."

The Prophet PBUH then said, "tie up your camel first then put your trust in God."

Table 1 Risks in Islamic financial services

Type of risk Coverage

Financing risk Attributed to delayed, deferred, and default in payments by counterparties. Covers profit-sharing contract (Mudãrabah and Mushãrakah), receivables and lease (Murãbaha, Diminishing Mushãrakah, and Ijãrah), and working capital financing (Salam, Istisnã, and Mudãrabah). Covers different stages of a contract.

Market risk Attributed to adverse movements in interest rates, commodity prices, and foreign exchange rates. Covers commodity risks existing in Murãbaha and Ijãrah contracts.

Equity risk Attributed to adverse changes in market value (and liquidity) of equity held for investment purposes. Covers all equity instruments (Mudãrabah and

${ }^{10}$ Ibid. 


\section{Mushãrakah).}

Liquidity Risk Attributed to adverse cash flow in situations arising mainly out of changing market risk exposures, credit risk exposures, and operational risk exposures

Rate of return Attributed to changes in account holders' expectations of the risk return on investments. Also related to fluctuations in returns due to changes in underlying factors of the contract.

Operational risk Attributed to the inadequacy of failed processes, people, and systems. Also includes risks arising from Shariah non-compliance.

Legal risk Attributed to the inadequate legal framework, conflict of conventional and Islamic laws, and conflict between Shariah rulings and legal decisions.

\section{Source: adapted from Akkizidis and Khandelwal (2008:39)}

Islamic financial firms offer instruments based on equity investments. The two contracts generally used for these instruments are mudaraba (partnership) and musharaka (joint venture partnership). Equity investment risk arises because of a potential decrease in the fair value of the equity position held by the Islamic firm. A firm's equity participation can range from direct investment in projects or joint venture businesses to indirect sharia-compliant investment, such as in stocks. If the firm faces a decline in the value of its equity position, it can lose any potential return on its investments and may even lose its invested capital. This situation can trigger additional problems, such as credit risk and liquidity risk.

\section{H. Anticipating Equity Financing Risks}

The Islamic firm can try to reduce equity risk by analyzing certain key factors, including the following, before entering a contract:

(a) The background and business plan of the managing partner or management team. The business must not involve speculative behavior, gambling, and use borrowing from conventional banks as a source of fund.

(b) The projected legal and economic environment in which the project will take place. Islam prohibits environmental destructions therefore investing in the project, Islamic banks 
must ensure the legal and economic environment of the business to avoid conflict with stakeholders which may result in further loss.

(c) In addition, the firm must continue to monitor the investment after the contract is signed to avoid information asymmetry with its partner(s). To avoid false profit and loss statements while determining the amount of profit sharing, Islamic banks may place account officer as a representative to supervise the partners' business activities.

\section{Displaced commercial risk}

Islamic financial institutions don't provide fixed returns in exchange for their customers' deposits or investments. Instead, people who provide funds expect to share profits and losses with the firm.

The shared-risk-and-reward scenario is nice in theory, but in practice, investors expect returns! If they don't get them, they may move their money to other financial institutions. This becomes more likely as more Islamic banks and other firms enter the marketplace and sharia-compliant customers' options increase. As a result, Islamic firms face displaced commercial risk; they're forced to pay returns to fund providers even if the underlying assets don't earn profits. To deal with this type of risks Islamic banks must: first, to ensure customers always get returns even in a condition of sour, Islamic banks must be willing to allocate certain amount of its own profit sharing or waives ups fees from investment projects; second there is a need for creating reserve funds by allocating certain percentage of yearly profit to anticipate loss in investment; third, implementing control systems to ensure that every single investment are safe and able to generate maximum

\section{J. Rate of return risk in Islamic finance}

This type of risks occurs as a result of unexpected changes in the market rate of return, which adversely affect a firm's earnings. Unlike conventional banks - with their fixed return- Islamic banks returns depends largely on the performance of the investment project. Investors are required to share both profits and losses with the institution.

Even though customers of Islamic banks understand the risks of placing their funds on profit and loss sharing mode of financing, they may react negatively - and possibly pull out their funds - if a firm's returns are lower than market rates. Rational customers demand for higher return as the market 
rate increase, thus putting pressure on Islamic banks to provide more returns than its asset earnings alone may merit. If Islamic banks fail to respond to the market rate increase, it may lead to liquidity risk (because customers may withdraw funds too rapidly). If it responds to the market pressure, it creates displaced commercial risk and must take the steps outlined in the preceding section.

\section{K. Sharia noncompliance risk}

Sharia compliance is the reason Islamic financial institutions exist. If a firm isn't adhering to sharia principles and guidelines, the impact can be severe. If one or more Islamic scholars indicate that an Islamic firm is veering away from compliance, its reputation will sink.

Very briefly, here's what compliance with sharia principles looks like:

(a) Complying with minimum requirements from the start: An Islamic firm must do a few key things to distinguish itself from a conventional financial institution: avoid interest, gambling, and speculation; steer clear of investing in prohibited industries; and include a sharia board in its corporate governance structure.

(b) Keeping transactions and operations in compliance: Even if a firm starts out in compliance, its internal controls must ensure that transactions and operations are analyzed on an ongoing basis. A sharia board is responsible for conducting regular sharia audits to look for any possible noncompliance that may undermine the firm's reputation.

(c) Developing compliant products: Every product developed by an Islamic financial institution must go through the institution's sharia board for approval. When internal approval is secured, the product goes to outside regulators, who also consider its sharia compliance and may reject it if they have compliance concerns. The firm's internal controls must outline this process carefully so that any product sent to regulators for consideration is, without a doubt, sharia-compliant.

Islamic scholars make their decisions based on their interpretations of source materials, and interpretations differ. A firm's internal sharia board may approve a new product only to have regulators reject it. Conversely, a firm's sharia board may reject a product idea that is later approved by another institution. In these situations, a company's stakeholders may ask for additional confirmation regarding a product's sharia-compliance. This product development risk is unique to the Islamic finance industry. 


\section{Risk Sharing Model in Islamic Financial System}

While a number of noted economists have advocated a financial system that limits debt creation, Islamic finance addresses the problem by replacing debt with equity finance. ${ }^{11}$ In essence, Islamic finance is a financial system structured on risk-sharing and the prohibition of debt financing. Islamic finance prohibits transactions that charge rents (i.e., interest) as a percentage of principal without the transfer of the property rights to the lender. For example, if a bond is issued to finance a real estate project, the purchasers of the bond would participate in the risk associated with the project by having property rights over the project's assets so that in the case of a failed project, their compensation would be limited to these assets. Thus, Islamic finance prohibits shifting the entire risk of the transaction to the borrower. The Quran prohibits debt based contracts, but simultaneously ordains an alternative ${ }^{12}$ : a mutual exchange in which one bundle of property rights is exchanged for another, thus allowing both parties to share production, transportation, and marketing risks. It allows parties to enter into a contract to share, and thus reduce, the risk of income volatility. In order to fit into this framework, the Islamic financial system would be a two-tier banking system ${ }^{13}$. First, banks would accept deposits for safekeeping without accruing any return, and must maintain one hundred percent reserves. This protects the payment system of the economy, while concurrently limiting the credit-creating ability of the banking system. Second, an investment component would function as a financial intermediary, channeling savings into investment projects. Deposits in these investment banks would be considered equity investments with no guarantees for their face value at maturity, and subject to the sharing of profits and losses. Depositors would be investors in the pool of assets maintained by the investment bank on the asset side of its balance sheet. These banks invest directly in real projects in every segment of the economy (except in prohibited activities like gambling and alcohol) and share in their attendant risk. An Islamic bank is assumed to match deposit maturities with investment maturities, with no need for asset-liability management. Short-term deposits may finance short-term trade operations, with liquidity replenished as sales operations generate profits. For long-term investments, longer-term deposits are used. In such operations, financial institutions participate directly in the evaluation, management, and monitoring ofthe investment process. Returns to invested funds are determined only after there arerealized profits or losses, and are distributed to depositors as if they were shareholders ofequity capital. Returns and losses are directly associated

\footnotetext{
${ }^{11}$ Ibid., p. 5 .

${ }^{12}$ Ibid.

${ }^{13}$ Ibid.
} 
with real activities, as opposed to those that are purely financial, because banks following the Islamic model would be prohibited from investing in debt-based financial instruments. Since loan default is absent, depositors do not risk losing their assets. Therefore, in Islamic finance, there is a one-to-one relationship between the growth of the real sector and the financial sector: credit cannot expand or contract independently of the real economy, unlike the conventional financial system that encourages uncontrolled credit creation and leveraging. In order for the Islamic financial system to fulfill its mission of financial intermediation, it is essential for capital markets-like stock markets and other secondary capital markets - to be well developed. As such, governments could become active in stock markets for risk-sharing. They could choose to finance part of their budget - or at least their development spending - through risksharing and direct ownership of development projects with their citizens; this way, governments could also reduce their budgetary debt burden. The attendant reduction in government borrowing in turn would reduce the burden on monetary policy. In place of debt, Islamic finance introduces securitized "assetlinked" securities. The key difference, between conventional securitization and asset securitization in Islamic finance is the end investor's ownership rights, or access, to the securitized assets. In the conventional system, there are multiple layers of ownership, which may leave the final investor without any recourse in case of default. In the Islamic system, there are strict requirements of clear ownership rights for the investor. This feature affords a measure of stability because the same underlying asset is not traded multiple times, which could have a cascading effect in the case of liquidation. More importantly, in conventional securitization, the underlying assets are debt-based, and thus have an implicit guarantee of the principal. Securitization in the Islamic system, on the other hand, is based on equity or risk-sharing, and thus the principal return would depend on the market value of the underlying asset. Again, this is an important structural element that reinforces financial stability. An Islamic, asset-linked security complements the risk-return profile of a typical stock market security in one crucial way: while an equity share represents ownership in the equity capital of a firm and is thus exposed to general risk in the business of the firm, an asset-linked security represents a security where the investor's return is linked to the profit and loss of a pool of heterogeneous assets. As a result, the expected volatility of such asset-linked securities is lower when compared to a simple stake in equity capital, assuming that there is no change in the creditworthiness of the asset owner. Due to low volatility, asset-linked securities can cater to the needs of investors who would like more deterministic and low-risk returns. 


\section{Stimulating Equity Based Financing}

To foster the development of Islamic finance in any country, first and foremost the system needs to emphasize risk-sharing ${ }^{14}$. The bias against equity finance - or adverse taxation of equity finance relative to debt-must be removed in order for risk-sharing and equity finance to flourish. Additionally, given the importance of the stock market for equity finance, regulators should reduce the transaction costs of stock market participation, develop low-cost, efficient secondary markets for trading equity shares, and also promote longterm financing instruments. It is imperative to create a marketbased incentive structure in order to minimize speculative behavior. Secondary markets would promote better distribution of risk, and achieve risk reduction by keeping expected payoffs in line with overall stock market performance. Absent true risksharing, Islamic finance may simply encourage debt-like, short-term, lowrisk, and highly-liquid financing without manifesting the most important dimension of Islamic finance: its ability to facilitate high growth in employment and income with relatively low risk to individual investors and market participants. Financial intermediation is at the heart of any financial system. Since those who invest are not necessarily those who save, efficient financial intermediation essentially channels savings to the most productive investments. Its traditional function has been to transfer savings to firms, entrepreneurs, and governments for investment, and increasingly to transfer risk to those who are better able to assume it. Historically, financial intermediaries have provided these services, but in recent years, financial and capital markets have progressively served the same functions. While intermediaries and markets could complement one another, enhanced competition between markets and intermediaries can be expected to increase efficiency and risk-taking. Sensible institutions and governance are crucial for the development of a sustainable financial system. Given the moral hazard and agency problems associated with equity based financial contracts, institutions that govern property rights and enforce the terms and conditions of contracts provide a reasonably strong basis for an economy based on risk-sharing, where information flows unhindered and participants engage in transactions confidently and with minimal uncertainty. As can be readily inferred, strict rule compliance is absolutely essential for an Islamic financial system to live up to its name and expectations. Human frailty being what it is, effective institutions and enforcement are essential prerequisites for a successful and stable financial system. Despite its origins, the development of Islamic finance is limited even in Muslim countries themselves. In recent years, the number of Islamic banks and their assets has increased significantly and Islamic financial products, specifically sharia-compliant

${ }^{14}$ Ibid. 
products, have been rapidly developed and sold by Islamic and non-Islamic banks around the world. Nevertheless, while Malaysia has adopted policies that are moving its financial system toward one resembling Islamic finance, no country has a system that could be fully classified as such. Weak economic and financial infrastructure, inefficient and unreliable institutions, and underdeveloped human capital stymie the potential of a truly Islamic financial system in most Muslim countries. The ethical and moral practices demanded by Islam stand as one of the greatest underlying challenges of developing this system in a highly profit-hungry world. According to the Quran, a society must be based on a foundation of social justice, and individual members of society must be committed to ethical standards in all of their dealings. In such a setting, greed, corruption, and speculation would be minimized, and the government would develop and enforce rules that would benefit society.

\section{N. Conclusion}

One way to eliminate recurring financial crises is by encouraging risksharing and equity financing. While Islam offers a system that prohibits all debt, a significant reduction in debt financing in favor of risk-sharing is the essential ingredient to reduce and eliminate financial crises. The world needs a financial system that reduces risk-shifting and debt financing in favor of risk-sharing and equity financing in order to create a financial system that promotes growth and minimizes instability. Islamic banks must identify and make assessment on the nature and forms of business risks. There are several forms of risks face by Islamic banks namely strategic risks, financial risks, sharia-compliance risk and operational risks. Strategic risks can be reduced by enhancing risk governance strategy while financial risks can be reduced through standardize disclosure procedures on valuation, liquidity and financing risks. Meanwhile shariacompliance risk can be optimized along the process of decision making starting from sharia supervisory board until investment managers. Finally operational risks can be mitigated by enhancing coordination among business process, human capital, technology and sharia compliance that impact overall Islamic banks performance. 


\section{REFERENCE}

Akkizidis, I. and Khandelwal, S. 2008, Financial Risk Management for Islamic Banking and Finance, Hampshire: Palgrave Macmillan

Al-Hilali, M. T. \& Khan, M. M. (1996). The Noble Qur'an: English Translation of the Meanings and Commentary. King Fahd Complex for the Printing of the Holy Qur'an, Madina

Al-Omar, F. and Mohammed, A. H, 1996, Islamic Banking, Theory, Practice and Challenges, London: Oxford University.

Antonio, M. Syafi'i. 2001. Bank Syariah : Dari TeorikePraktik . Gema Insani Press. Jakarta.

Askari, H.2012.Islamic Finance, Risk-Sharing, and International Financial Stability. Yale Journal of International affairs. March Edition.

Chapra, M. U. and Khan, T. 2000, 'Regulation and Supervision of Islamic Banks', Occasional Paper No. 3, Islamic Research \& Training Institute, Saudi Arabia

Hassan, .M. K., 1992. “An Empirical analysis of Bank Standby Letter of Credit Risk," Review of Financial Economics, 2 (1)

Hassan, M.K., 1993. "Capital market tests of Risk Exposure of Loan sales", Quarterly Journal of Business \& Economics 32 (1).

Hassan, M.K., Karels, G.V. and Peterson, M.O., 1994. "Deposit Insurance, market discipline and off-balance sheet banking risk of large U.S. commercial banks," Journal of Banking and Finance 18

Hassan,M.K. and Bashir,A.H.,2002.”Determinants of Islamic Banking Profitability" ERP paper.

Hassan, M.K and Lewis, M.K. 2007, Islamic Banking and Finance at the Crossroad, can be accessed online via file://D:/kuliah/ISLAMIC\%20FINANCE/hassan-lewis-praesentation.pdf

Karim, A.A. 2002a, Ekonomi Islam Suatu Kajian Ekonomi Makro Edisi Pertama, The International Institute of Islamic Thought (IIIT), Jakarta.

Karim, A.A. 2003b, Bank Islam: AnalisisFiqihdanKeuangan, The International Institute of Islamic Thought (IIIT), Jakarta.

Karim, A.A. 2004, Bejana Berhubungan Bank Syariah, http://www.republika.co.id/koran.asp?kat_id=15. 
Muhamad. 2004. Teknik Perhitungan Bagi Hasil dan Profit Margin pada Bank Syariah. Yogyakarta: UII Press.

Muhamad. 2005. Manajemen Bank Syariah Edisi Revisi. Yogyakarta: Unit Penerbit dan Percetakan (UPP) AMP YKPN.

Muhamad. 2005. Permasalahan Agency dalam Pembiayaan Mudharabah Pada Bank Syariah di Indonesia. Disertasi. Yogyakarta: UII Yogyakarta.

Sudarsono, H. 2008, Bank dan Lembaga Keuangan Syariah, Deskripsi dan Ilustrasi. Yogyakarta: Ekonisia

Sundararajan, V. and L. Errico, L. 2002, 'Islamic Financial Institutions and Products in the Global Financial System: Key Issues in Risk Management and Challenges Ahead', IMF Working Paper No. WP/02/192, International Monetary Fund 